While this work was in progress, Hechter, Lev and Soskin $^{1}$, following the work of Reynolds ${ }^{2}$ and Pompen $^{3}$, showed that vaginal cornification in the mouse produced by ostradiol benzoate may be inhibited by atropine, and that cornification follows the administration of yohimbine. The uterine response was only partially inhibited by atropine. Hechter and his co-workers believe that the vaginal response, and part of the uterine response to œstrogens, is dependent upon hyperæmia, a conclusion which is complementary to our own, since we found no indication of a direct action of cestrogens upon the epithelial cells.

$$
\text { C. W. Emmens. }
$$

National Institute for Medical Research, Hampstead, London, N.W.3.

Laboratories of the

R. J. LUdFORD.

Imperial Cancer Research Fund, Mill Hill.

${ }^{1}$ Hechter, O., Lev, M., and Soskin, S., Endocrinology, 26, 73 (1940). ${ }^{2}$ Reynolds, S. R. M., J. Physiol., 95, 258 (1939).

${ }^{3}$ Pompen, A. W. M., "De Invloed van Menformon op der Baarmoeder". Thesis, Amsterdam, quoted by Reynolds (1933).

\section{'Coupling' of Phosphorylation with Oxidation of Pyruvic Acid in Brain Tissue}

LIPMANN $^{1}$ found that, although adenylic acid does not influence the rate of oxidative decarboxylation of pyruvic acid by preparations of lactic acid bacteria, it is phosphorylated to adenosine-polyphosphate. With brain dispersions it has been shown in this laboratory ${ }^{2}$ that oxidation of pyruvate requires the presence of both inorganic phosphate ${ }^{3}$ and adenine nucleotide (adenylic acid, adenosine-triphosphate). These observations suggested that a cycle of phosphorylation is involved in the enzymatic oxidation of pyruvate.

Brain preparations contain an active adenosinetriphosphatase ${ }^{2}$ and, in the presence of adenylic acid (without or with creatine), only small amounts of adenosine-polyphosphate (or creatine phosphate) accumulate. However, that oxidation of pyruvate in brain tissue is accompanied by an intensive esterification of phosphate has now been shown by using hexosemonophosphate as an acceptor for the labile phosphorus groups of adenosine-triphosphate ${ }^{4}$. When hexosemonophosphate is added to a dialysed brain dispersion containing phosphate, $\mathrm{Mg}++5$, adenylic acid, fumarate ${ }^{2}$, pyruvate, and NaF (phosphorylation also occurs in the absence of $\mathrm{NaF}$ ), and the mixture is incubated aerobically, inorganic phosphorus is taken up (Table 1) and an equivalent amount of

TABLE 1.

$1.5 \mathrm{ml}$. dispersion from pigeon brain (dialysed $2 \cdot 5$ hours) to $2 \cdot 2 \mathrm{ml}$. with phosphate buffer $p \mathrm{H} 7 \cdot 3(0.05 M) \mathrm{Mg}{ }^{+}+(0.2 \mathrm{mgm}$. $)$, adenylic acid $(0.0007 M)$, Na fumarate $(0.005 M)$, Na pyruvate $(0.013 M)$ and $\mathrm{NaF}^{\prime}(0.04 \mathrm{M})$. Air, $38^{\circ}$.

$\left(\mathrm{O}_{2}\right.$ uptake $=$ difference between complete samples and samples containing no pyruvate + fumarate).

\begin{tabular}{|c|c|c|c|}
\hline $\begin{array}{c}\text { Time } \\
\text { (min.) }\end{array}$ & $\begin{array}{c}\mathrm{O}_{2} \text { uptake } \\
(\mu 1)\end{array}$ & $\begin{array}{c}\text { Pyruvic acid } \\
\text { (mgm.) }\end{array}$ & $\begin{array}{c}\text { Inorg. } \\
\text { Phosphorus } \\
\text { (mgm.) }\end{array}$ \\
\hline 0 & - & $2 \cdot 17$ & $1 \cdot 42$ \\
5 & 48 & $1 \cdot 62$ & $1 \cdot 13$ \\
10 & 96 & $1 \cdot 51$ & $1 \cdot 00$ \\
20 & 143 & $1 \cdot 34$ & 0.92 \\
30 & 190 & $1 \cdot 24$ & 0.83 \\
\hline
\end{tabular}

hexosemonophosphate is converted into hexosediphosphate. As much as $0.8 \mathrm{mgm}$. hexosemonophosphate phosphorus can thus be phosphorylated in 35 min. at $38^{\circ}$. The hydrolysis curve (in $N \mathrm{HCl}$ at $100^{\circ}$ ) of the resulting ester is that of hexosediphosphate which, under these conditions, does not seem to react further significantly ; this is confirmed by the failure to detect formation of phosphoglyceric acid by Rapoport's ${ }^{6}$ method. No esterification of phosphate occurs in the absence of pyruvate plus fumarate and very little in the absence of adenylic acid. Thus oxidation of pyruvate is accompanied by phosphorylation of adenylic acid to adenosine-polyphosphate which, in presence of hexosemonophosphate, transfers its labile phosphorus to the latter instead of being hydrolysed by the adenenosine-triphosphatase. Table 2 shows that, in $30 \mathrm{~min}$., approximately 2 atoms phosphorus are esterified for 1 mol. pyruvate disappearing and 1 mol. oxygen taken up.

TABLE 2.

\begin{tabular}{|c|c|c|c|c|c|c|}
\hline \multirow[t]{2}{*}{$\begin{array}{c}\text { Time } \\
\text { (min.) }\end{array}$} & \multicolumn{2}{|c|}{$\mathrm{O}_{2}$ uptake } & \multicolumn{2}{|c|}{$\begin{array}{c}\text { Pyruvic acid } \\
\text { disappeared }\end{array}$} & \multicolumn{2}{|c|}{$\begin{array}{c}\text { Phosphorus } \\
\text { esterifled }\end{array}$} \\
\hline & $\mu 1$ & $\mu \mathrm{mol}$ & mgm. & $\mu \mathrm{mol}$ & mgm. & $\mu$ atoms \\
\hline 30 & 190 & $8 \cdot 5$ & 0.93 & $10 \cdot 5$ & 0.59 & $19 \cdot 0$ \\
\hline
\end{tabular}

The necessity of inorganic phosphate and adenine nucleotide for the oxidative breakdown of pyruvate in brain is thus explained. The recent work of Warburg and Christian ${ }^{7}$, by which the mechanism of enzymatic oxidation of triosephosphate and the true nature of the 'coupled' esterification of phosphate are made clear, will throw much light upon the undoubtedly similar mechanism of pyruvate oxidation.

I am indebted to the Nuffield Trustees and the Rockefeller Foundation for grants in aid of this work.

Department of Biochemistry,

S. OCHOA.

Oxford.

April 11.

1 NATURE, 143, 281 (1939)

2 Banga, Ochoa and Peters, Nature, 144, 74 (1939); Biochem. J. 33, 1980 (1939).

3 ef. Lipmann, Enzymologia, 4, 65 (1937) as regards bacteria.

${ }^{4}$ Ostern, Guthke and Terszakowec, $Z$. physiol. Chem., 243, 9 (1936).

${ }^{5}$ Ochoa, Nature, 144, 834 (1939).

'Biochem. Z., 291, 429 (1937).

'Biochem. Z., 308, 40 (1939).

\section{Influence of Spermathecal Stimulation on the Physiological Activities of Anopheles subpictus}

THE introduction of spermatozoa into the spermatheca is not known to influence the physiological activities of a mosquito or of any other insect except that it serves the purpose of fertilization of the ovum. That it has a marked action on egg formation in Anopheles subpictus has now been demonstrated.

While successful mating of $A$. stephensi and A. annularis can take place in ordinary feeding cages in the laboratory, $A$. subpictus do not pair under similar conditions, a fact which has also been noted by Christophers ${ }^{1}$. The proclivity of the three species of anophelines mentioned above to feed on blood is independent of mating, though $A$. subpictus do not 